\title{
Research on the Functions of the State-Owned Economy in China and Abroad Under the New Circumstances
}

\author{
Jianfei Lu*, Jin Liu and Suxiu Li
}

State Grid Energy Research Institute, China, 102209

*Corresponding author. Email: feixiaruc@163.com

\begin{abstract}
At the first meeting of the state-owned enterprise reform leading group of the State Council, vice premier Liu he clearly pointed out that it is necessary to strengthen the research on the functions of the state-owned economy under the new situation. Nowadays the international political and economic situation has become increasingly complex, which constitutes a new trend of the whole economic and social development. One of the focuses of Sino US trade disputes is the issue of state-owned enterprises, which indicates the preferential measures of the Chinese government for stateowned enterprises lead to the inability of foreign-funded enterprises to participate in fair competition and lead to global overcapacity. Based on this, this paper refines and summarizes the concept and functions of state-owned economy in China and puts forward some optimization suggestions for promoting the high-quality development of China's stateowned economy.
\end{abstract}

Keywords: State-owned economy, Small and medium economy, Reform and opening-up.

\section{INTRODUCTION}

China`s economy and society have entered a new historical stage. The driving forces of national economic growth have undergone major adjustments while emerging technologies have advanced rapidly. The international political and economic situation has become more and more complex. One of the focal points of SinoUS trade disputes is the issue of state-owned enterprises in China. The United States argue the Chinese government's preferential measures for state-owned enterprises have prevented foreign-funded enterprises from participating in the market competition fairly and led to excess production capacity worldwide. This research focuses on the concept of the state-owned economy in China. Based on the analyzation of the development stage and the external environment in China, this research refines and summarizes the functions of the state-owned economy in China. Finally, it puts forward the development suggestions of state-owned economy in China.

\section{THE CONCEPT OF STATE-OWNED ECONOMY IN CHINA}

Regarding the concept of state-owned economy in China, it means the socialist economy of ownership by the whole people, which is the dominant force in the national economy. From the perspective of the socialist economic system, the state-owned economy refers to a socialist economy owned by the whole people. From the perspective of the division of economic types, the stateowned economy refers to an economic component whose assets are owned by the state.

Regarding state-owned enterprises, based on the analyzation of the policies about state-owned enterprises by the State-owned Assets Supervision and Administration Commission, the Ministry of Finance, the Development and Reform Commission and other government ministries, state-owned enterprises refer to wholly state-owned enterprises, wholly state-owned companies, and state-owned capital holding companies that the State Council and local people's governments perform on behalf of the state as investors. From the perspective of corporate capital composition, stateowned enterprises are funded by the State Council and 
local people's governments on behalf of the state. From the perspective of economy control, only absolute holding companies with more than 50\% state-owned equity are state-owned enterprises. From the perspective of reform requirements, state-owned enterprises are owned by the whole people, which is an important force for advancing the modernization of the country, safeguarding the common interests of the people, also an important material and political foundation for the development of China.

Regarding state-owned assets, it can be divided into operational assets formed by the state's investment in enterprises, administrative assets managed by state agencies, state-owned institutions and other organizations, as well as resource assets such as land, minerals, forests, and water that belong to the state. Since the administrative and institutional assets and resourcebased assets have corresponding administrative regulations and special laws to regulate and adjust, the "State-owned Assets Law of the People's Republic of China" only applies to the state-owned assets of enterprises and refers to the state's various forms of capital contributions to enterprises.

Regarding state-owned capital, the "Interim Measures for the Confirmation of the Results of Value Preservation and Appreciation of State-owned Capital of Enterprises" stipulates that it refers to the state's various forms of investment in enterprises and the rights and interests formed by investment in enterprises, as well as other rights and interests that are recognized as state-owned in accordance with the law. For instance, the state-owned capital of a wholly state-owned enterprises refers to the owner's equity of the enterprise, as well as other rights and interests recognized as owned by the state according to law; for state-owned holding and shareholding enterprises, its state-owned capital refers to the share of the owner's equity of the enterprise that the state should enjoy.

\section{THE FUNCTION OF STATE-OWNED ECONOMY IN CHINA}

From the perspective of policy requirements, the function of the state-owned economy as the dominant economy force has remained unchanged. The connotation of the state-owned economy in the national economy and its role in economic development has been continuously enriched and improved. To be specific, the state-owned economy was firstly positioned as the leading force in the national economy. And then the stateowned economy has become the dominant force in the national economy. The government firstly guaranteed priority development the state-owned economy, and then the government guarantees the consolidation and development of the state-owned economy. State-owned economy firstly controlled the lifeline of the national economy, and then state-owned economy has played a leading role, aiming to improve control capability, influential capability, international competitive capability risk control capability.

Based on some researches, the basic functions of the state-owned economy are mainly reflected in four aspects: first, the state-owned economy is an effective means to solve market failure. It is working through providing public products at the national level, solving natural monopoly problems through state-owned enterprises (such as railways, highways, power and other sectors), and expanding public expenditures to solve the problem of insufficient effective demand. Especially when the economy is in recession, the government make a difference through expanding public expenditure and investing infrastructure construction by state-owned economy. Second, the state-owned economy is an important source of increasing government revenue. In addition to taxation, state-owned economy, state-owned assets and state-owned enterprises are important ways to increase government revenue. Third, the state-owned economy is conducive to controlling industries related to the lifeline of the national economy and national security and reduces the impact that the country may have on the national economy when facing external shocks. Fourth, the state-owned economy is conducive to improving the international competitiveness of domestic enterprises.

From the perspective of development practice, China`s socialist basic economic system has been continuously improved since 1978. And the strategic adjustment of the state-owned economy has continued to advance, as well as the quality and competitiveness of state-owned enterprises have been continuously enhanced. On one hand, state-owned enterprises maintain controlling position in important strategic areas. It is mainly reflected in the oil and natural gas extraction industry, coal mining industry, nuclear fuel processing industries, and power production industry. In terms of foreign economic and trade, the key areas and leaders of China's foreign investment are still concentrated in the energy and transportation fields, and the state-owned components in these fields occupy a large proportion. In terms of industrial development, the core competitiveness of state-owned enterprises has continued to increase. In the fields of UHV power transmission and transformation, manned aerospace, and mobile communications, a number of major scientific and technological innovations of the world's advanced level have been achieved. On the other hand, state-owned enterprises are gradually withdrawing in general competitive fields. Both the number of enterprises and the total economic volume of the state-owned economy are significantly decreasing. Mainly reflected in food manufacturing, beverage manufacturing, textile and clothing, furniture manufacturing, pharmaceutical manufacturing, building materials, metal products, instrumentation, agricultural and sideline food 
processing, general equipment manufacturing and other industries.

\section{ENLIGHTENMENT AND SUGGESTIONS FOR THE DEVELOPMENT OF STATE-OWNED ECONOMY UNDER THE NEW SITUATION}

China has become one of the leading economies in the world. In 2018, China's industrial output value accounted for $30 \%$ of the world's industrial growth while its industry rate was a positive growth of 4\%; the US's industrial output value accounted for $17 \%$ of the world's industrial growth while its industry rate was a negative growth of 1\%; Japan's industrial output value accounted for $7 \%$ of the world's industrial growth while its industry rate was a negative growth rate of $1 \%$. Nowadays, the international economic structure has undergone major adjustments, and the multilateral system is facing a crisis, The restructuring of global trade and investment rules has brought tremendous pressure and challenges to the further development of the state-owned economy. As Sino-US economic and trade frictions continue to intensify, trade protectionism is on the rise, globalization has entered a period of in-depth adjustment and transformation, and the international competition landscape is showing a complex and changeable situation. The international economic and trade environment for state-owned enterprises in China has undergone profound changes. First, the international economic and trade rules will become increasingly stringent. For example, the Comprehensive and Progressive Trans-Pacific Partnership Agreement (CPTPP) requires the cancellation of tax incentives, subsidies, preferential transactions, and non-commercial support for state-owned enterprises. Restricting the noncommercial support of state-owned enterprises has become one of the trends in international economic and trade rules. Second, the laws and regulations of different countries have become more and more stringent, and the penalties for violations have become increasingly serious. The scope of penalties has also extended to labor, environmental protection, privacy protection, antimonopoly, intellectual property protection and other fields, and legal compliance risks have increased. Third, under the background of Sino-US economic and trade frictions, Chinese enterprises are facing additional tariff sanctions on exports. For example, the United States included many companies on the "Entity List" and the export control export list. These measures have imposed considerable restrictions on state-owned enterprises in China going out. As a result, this paper suggests stateowned enterprises in China should make several changes as below:

\subsection{SOEs Strengthen the Competition and Cooperation Power Based on the Comprehensive Evaluation Of International Society, Bilateral And Multilateral Rules}

Strengthening the competition and cooperation power will not only cultivate state-owned enterprises into world-class enterprises, further release the vitality and reform momentum of state-owned enterprises, but also enhance the state-owned economic strength and the country's overall competitiveness. State-owned enterprises should make contribution on ensuring the related disputes are recognized by the international community:

Firstly, state-owned enterprises should learn from the successful experience of China's accession to the WTO and evaluate the relevant provisions on SOEs. The Government modify or adjust the current corresponding laws according to applicable clauses and retain the laws for inapplicable clauses.

Secondly, state-owned enterprises should learn from the evasion measures of foreign governments or enterprises to make corresponding transformations based on overall evaluation of international disputes over tax incentives, subsidies, preferential transactions, and noncommercial support for state-owned enterprises. For example, in response to the international concern that the Chinese government's subsidies to state-owned enterprises, it is recommended that government should make it be transparent and legalized through the establishment of funds.

\subsection{SOEs and the government should summarize advanced practices of typical countries in promoting and driving the development of SMEs}

Firstly, the government should establish a special management agency for SMEs. Because small and medium-sized enterprises are in the disadvantaged position in the social economy, the development resources are insufficient. SMEs' various rights and interests are easily infringed. Therefore, it is necessary to have a special management agency for SMEs to help them in market competition. The main responsibilities of the management organization are roughly as follows: to provide consultation to small and medium-sized enterprises, to provide management technical assistance; to provide financial support to small and medium-sized enterprises; as the spokesperson for small and mediumsized enterprises, to coordinate with other relevant government agencies, etc.

Secondly, the government should support the innovation of SMEs with national plans. The government is capable of encouraging SMEs to innovate through direct government funding, investment in equity, support 
for venture capital, and loan guarantees. There are many ways to support small and medium-sized enterprises through national plans, mainly including three types:

The first way is to encourage venture capital to fund small and medium-sized enterprises in the form of equity investment. The form of equity investment means that state invest venture capital companies, and then the venture capital companies select suitable projects or small enterprises to invest. The government supervises the investment plans of venture capital companies, and venture capital funds provide value-added services other than capital to the invested companies, including corporate management, business decision-making and financial advice. The purpose of the equity investment plan is to attract follow-up investment from private capital and create a vibrant venture capital market. For example, the Australian Innovation Investment Fund (IIF plan) was implemented in 1997 and is under the responsibility of the Australian Industry Research and Development Commission. It is committed to providing equity risk capital to small businesses in the early development stages. The goal of the plan is to encourage the development of new technology companies that commercialize $R \& D$ results and cultivate Australia's own venture capital market. The fund is selected by the government and managed by other agencies after the project is established. The Australian government provided US\$221 million for the plan to invest in 8-9 venture capital funds with a scale of roughly US\$40 million. The matching ratio between government funds and private funds is up to $2: 1$.

The second way is to make loan guarantee plan. The loan guarantee plan is the government guarantees a certain percentage of the loans that meet the requirements provided by financial institutions. When the borrower defaults, the loss borne by the lender is only that part of the unsecured loan. The purpose of the plan is to encourage financial institutions, especially commercial banks, to provide funding to small businesses that have good projects but cannot meet the mortgage requirements. As a substitute for collateral, government guarantees can let lenders know the maximum amount they may lose. For example, the SLFG plan in the United Kingdom is the British government's guarantee through government funds to guide banks to lend to newly created small businesses. As the guarantor in the loan guarantee scheme, the Ministry of Trade and Industry of the United Kingdom, small businesses submit a written application report to the Ministry of Trade and Industry, and then sign a loan agreement with the designated bank after approval. In this plan, the government guarantee amount is $75 \%-85 \%$ of the loan amount. When the loan fails, on the one hand, the bank can use government guarantee funds to avoid greater risks. At the same time, according to the loan agreement, the bank also has the right to dispose of the lender's private property to avoid remaining risks. This practice of guaranteeing funds from the government and assuming greater risks has effectively promoted bank loans to small businesses.

\subsection{The Government Should Adopt Preferential Tax Policies to Reduce the Operating Costs of SOEs and SMEs.}

In order to achieve the goal of promoting economic development, tax incentives are used as investment stimulation. Tax incentives for certain types of enterprises can attract many investors to enter these fields. Due to the expansion of investment scale and the role of investment multipliers, the economic development of the enterprise can be promoted. For example, the VCT plan in the United Kingdom is the British government bids fund management companies (VCT) from the public. Eligible companies are allowed to raise funds from the public on the London Stock Exchange and absorb private funds that are willing to invest in small companies for more than 5 years. VCT companies requires at least $70 \%$ of the funds to be invested in small businesses within 3 years. Investors who invest in VCT will enjoy a series of tax incentives: a reduction of income tax equivalent to $20 \%$ of their investment in the year of investment; exemption of income tax on original stock dividends; exemption of capital gains from stocks sold after 3 years' taxes etc. The VCT company itself can also enjoy the preferential treatment of exemption from capital gains tax when the investment is withdrawn.

\section{CONCLUSION}

Nowadays one of Sino US trade disputes is the issue of state-owned enterprises, which indicates the preferential measures of the Chinese government for state-owned enterprises lead to the inability of foreignfunded enterprises to participate in fair competition and lead to global overcapacity. Based on this, this paper refines and summarizes the concept and functions of state-owned economy in China and puts forward some optimization suggestions for promoting the high-quality development of China's state-owned economy.

\section{ACKNOWLEDGMENTS}

This work is supported by the Science and Technology Project of State Grid Corporation of China (1400-202157233A-0-0-00).

\section{REFERENCES}

[1] X Zhao, H Zhao. Research on the impact of social responsibility of state-owned enterprises and private enterprises on financial performance. International Journal of Electrical Engineering Education, 2021. DOI: http://dx.doi.org/10.1177/0020720921999744 
[2] H Wang, W Wang, S Alhaleh. Mixed ownership and financial investment: Evidence from Chinese stateowned enterprises. Economic Analysis and Policy, 2021(1).

DOI: https://linkinghub.elsevier.com/retrieve/pii/S03135 92621000266

[3] J Y Lin. State-owned Enterprise Reform in China: The New Structural Economics Perspective. Structural Change and Economic Dynamics, 2021.DOI:

https://doi.org/10.1016/j.strueco.2021.05.001

[4] H Bo, T Li, L A Toolsema. Corporate Social Responsibility Investment and Social Objectives:
An Examination On Social Welfare Investment of Chinese State Owned Enterprises. Scottish Journal of Political Economy, 2009, 56(3):267-295. DOI:https://onlinelibrary.wiley.com/doi/10.1111/j. 1467-9485.2009. 00484.x

[5] C Guo, D Wang, C Lu, et al. Research on Construction of Safety Management System in State-owned Enterprises[J]. Journal of Physics: Conference Series, 2021, 1827(1):012200 (7pp). DOI: $\quad$ http://dx.doi.org/10.1088/17426596/1827/1/012200 